Волченко Т.И.

\title{
ОСОБЕННОСТИ ОКАЗАНИЯ ПРАВОВОЙ ПОМОЩИ ТАМОЖЕННЫМИ ОРГАНАМИ РОССИЙСКОЙ ФЕДЕРАЦИИ ПРИ ПРОИЗВОДСТВЕ ПО ДЕЛАМ ОБ АДМИНИСТРАТИВНЫХ ПРАВОНАРУШЕНИЯХ
}

\begin{abstract}
Аннотация: В статье исследуется механизм оказания правовой помощи таможенными органами Российской Федерации по делам об административных правонарушениях, выделены его основные этапы. Кроме того, автор обращает внимание на то, что законодатель в главе 29.1 КоАП РФ не называет процессуальных действий, которые могут запрашиваться из-за рубежа путем направления запроса об оказании правовой помощи по делу об административном правонарущении. На основе толкования норм КоАП РФ, с учетом положений Соглашения о правовой помощи и взаимодействии таможенных органов государствчленов Таможенного союза по уголовным делам и делам об административных правонарушениях, автором рассматривается объем правовой помощи, запрашиваемой к исполнению таможенными органами Российской Федерации по делам об административных правонарушениях. Методологической базой исследования является диалектический материализм и основанная на нем система общенаучных и частнонаучных методов, в том числе: формально-логический метод, системный метод, метод сравнительного правоведения и др. На основе проведенного в статье анализа норм КоАП РФ, а также международных договоров о сотрудничестве и взаимопомощи в таможенных делах, автором рассмотрены основные этапы оказания правовой помощи таможенными органами Российской Федерации по делам об административных правонарушениях, обозначены их особенности. Кроме того, названы сами процессуальные действия, которые могут запрашиваться к исполнению путем направления запроса об оказании правовой помощи по делу об административном правонарушении.

Ключевые слова: правовая помощь, административные правонарушения, административный процесс, международное сотрудничество, таможенные органы, таможенные правонарушения, доказывание, запрос, направление запроса, исполнение запроса.
\end{abstract}

$\mathrm{B}$ процессе производства по делу об административном правонарушении должностные лица таможенных органов зачастую сталкиваются с необходимостью проведения процессуальных действий на территории иностранного государства, а также получения необходимой для производства по делу информации и документов. Такое положение объясняется тем, что особенностью административных правонарушений в рассматриваемой области является наличие в них так называемого «иностранного элемента». Это связано с тем, что таможенное дело, как специфическая область деятельности, включает в себя регулирование перемещения товаров и транспортных средств через таможенные границы государств ${ }^{1}$. Получаемая же информация позволяет успешно завершать производство по делам

\footnotetext{
Зубач А.В., Пятикова Е.А., Хомяков Л.Л. Аминистративно-юрисдикционная деятельность таможенных органов: монография. - М.: РТА, 2009. - С. 38.
}

о нарушении таможенных правил, выявлять и пресекать таможенные правонарушения.

В этой связи, важнейшей новацией федерального законодательства об административных правонарушениях является недавнее закрепление в Кодексе Российской Федерации об административных правонарушениях (далее - КоАП РФ) такой формы межгосударственного сотрудничества при производстве по делам об административных правонарушениях как оказание правовой помощи. Дополнившая текст КоАП РФ глава 29.1 «Правовая помощь по делам об административных правонарушениях», устанавливает порядок направления и исполнения запроса о правовой помощи по делу об административном правонарушении, регламентирует его содержание и форму, определяет юридическую силу доказательств, полученных на территории иностранного государства.

Следует отметить, что механизмами оказания правовой помощи «наполнены» различные отрас- 
ли права. К примеру, ч. 1 ст. 4 Конвенции о правовой помощи и правовых отношениях по гражданским, семейным и уголовным делам, принятой 22 января 1993 г. в г. Минске, закреплен широкий ряд отраслевых направлений оказания правовой помощи: «Учреждения юстиции Договаривающихся Сторон оказывают правовую помощь по гражданским, семейным и уголовным делам в соответствии с положениями настоящей Конвенции» ${ }^{2}$.

В отечественном же правоведении вопросы оказания правовой помощи наиболее подробно разработаны в рамках уголовно-процессуального права. Сам термин «международное сотрудничество в сфере уголовного судопроизводства» впервые появился в уголовно-процессуальном законодательстве России в 2001 году в виде названия самостоятельной части 5 Уголовно-процессуального кодекса Российской Федерации (далее - УПК РФ). Вопросам же оказания правовой помощи посвящена глава 53 раздела XVIII части 5 УПК РФ, регулирующая основания, форму и порядок направления и исполнения запросов о правовой помощи по уголовным делам. Вместе с тем, как справедливо отметил А.Б. Новиков, «административно-юрисдикционный процесс не может «примерить на себя» по аналогии систему правового регулирования, относящуюся к тому или иному судебному процессу» ${ }^{3}$.

Анализ главы 29.1 КоАП РФ показывает, что механизм оказания правовой помощи по делам об административных правонарушениях включает в себя следующие действия (применительно к таможенным органам Российской Федерации).

Во-первых, подготовка запроса таможенного органа Российской Федерации об оказании правовой помощи и его направление в таможенный орган иностранного государства в установленном международным договором порядке в соответствии с требованиями национального законодательства запрашивающего государства (т.е. Российской Федерации).

Во-вторых, исполнение таможенным органом иностранного государства запроса таможенного органа Российской Федерации об оказании

\footnotetext{
2 О ратификации Конвенции о правовой помощи и правовых отношениях по гражданским, семейным и уголовным делам: федер. закон от 04 авг. 1994 г. № 16-Ф3 // Собр. законодательства РФ. - 1994. - № 15. - ст. 1684.

3 Новиков, А.Б. Совершенствование правового обеспечения правоохранительной деятельности таможенных органов / А.Б. Новиков // Внешнеторговое право. 2008. № 2. - Pежим доступа: СПС «КонсультантПлюс».
}

правовой помощи (либо принятие решения об отказе в исполнении), подготовка и направление официального ответа на данный запрос в установленном международным договором порядке в соответствии с требованиями национального законодательства запрашиваемого государства (т.е. иностранного государства).

В-третьих, получение ответа на исполненный запрос об оказании правовой помощи таможенным органом Российской Федерации (либо отказа в исполнении), проведение его юридической оценки, приобщение полученных документов, вещественных доказательств к материалам дела об административном правонарушении в соответствии с требованиями национального законодательства запрашивающего государства (т.е. Российской Федерации).

B-четвертых, исполнение таможенным органом Российской Федерации полученного от таможенного органа иностранного государства запроса об оказании правовой помощи (либо принятие решения об отказе в исполнении) и направление в иностранный таможенный орган официального ответа в установленном международным договором порядке в соответствии с требованиями национального законодательства запрашиваемого государства (т.е. Российской Федерации).

При этом важно отметить, что осуществление всех вышеперечисленных действий может быть необязательным.

Однако устанавливая механизм оказания правовой помощи по административным делам, законодатель не называет самих процессуальных действий, которые могут запрашиваться в целях получения доказательств из-за рубежа путем направления соответствующего запроса об оказании правовой помощи, а также процессуальных действий, которые могут быть запрошены к исполнению на территории Российской Федерации. Часть 1 статьи 29.1.1 КоАП РФ лишь устанавливает, что при необходимости производства на территории иностранного государства процессуальных действий, предусмотренных КоАП РФ, должностное лицо, осуществляющее производство по делу об административном правонарушении, направляет запрос о правовой помощи соответствующему должностному лицу или в орган иностранного государства. Буквальное толкование данной нормы позволяет сделать вывод о том, что таможенные органы Российской Федерации вправе запрашивать к исполнению только такие процессуальные действия, которые предусмотрены самим КоАП РФ. 
Важно также подчеркнуть, что международные договоры Российской Федерации о сотрудничестве и взаимной помощи в таможенных делах также не определяют тех процессуальных действий, которые могут быть запрошены к исполнению. В основном все они ограничиваются положением о том, что по запросу таможенной службы запрашивающего государства таможенная служба запрашиваемого государства проводит в соответствии со своим законодательством расследование.

Исключением является Соглашение о правовой помощи и взаимодействии таможенных органов государств-членов Таможенного союза по уголовным делам и делам об административных правонарушениях (далее - Соглашение), которое перечисляет процессуальные и иные действия, выполняемые таможенными органами государств-членов Таможенного союза на основании направленного запроса (поручения) по делу об административном правонарушении. Так, в соответствии с п. 1 ст. 10 Соглашения к таким действиям относятся: 1) Опрос лиц, в отношении которых ведется административный процесс (осуществляется административное производство), и свидетелей; 2) Изъятие либо арест товаров и документов, являющихся вещественными доказательствами или предметами административного правонарушения; 3) Истребование документов, необходимых для производства по делу; 4) Осмотр; 5) Получение необходимой для производства по делу или его рассмотрения информации от государственных органов и лиц; 6) Вручение документов или их копий участникам административного процесса (производства); 7) Экспертиза.

Отметим, что ранее В.В. Илясов, изучая вопросы административно-процессуальных действий, запрашиваемых к исполнению таможенными органами Российской Федерации в целях получения правовой помощи по делам об административных правонарушениях в период действия Таможенного кодекса Российской Федерации 1993 года, в качестве таковых выделял: 1) Опрос лица, привлекаемого к ответственности, и свидетелей; 2) Изъятие товаров, вещей, документов, транспортных средств и других предметов; 3) Наложение ареста на имущество, товары и другие предметы; 4) Осмотр как административно-процессуальная мера; 5) Назначение экспертизы, взятие проб и образцов для исследования; 6) Предъявление для опознания; 7) Получение необходимой для производства по делу и его рассмотрения информации; 8) Истре- бование документов; 9) Проведение ревизий, проверки, инвентаризации по делу.

Учитывая развитие российского законодательства на сегодняшний день, а также исходя из анализа норм КоАП РФ, международных многосторонних и двусторонних договоров Российской Федерации о сотрудничестве и взаимной помощи в таможенных делах, полагаем, что объём запрашиваемой правовой помощи должен ограничиваться следующими процессуальными действиями:

1) Получением объяснений лица, в отношении которого ведется производство по делу об административном правонарушении;

2) Получением показаний свидетелей по делу об административном правонарушении;

3) Проведением осмотра помещений, территорий и находящихся там вещей и документов;

4) Изъятием товаров и документов, являющихся вещественными доказательствами или предметами административного правонарушения;

5) Арестом товаров и иных вещей, являющихся вещественными доказательствами или предметами административного правонарушения;

6) Истребованием документов и сведений, необходимых для производства по делу об административном правонарушении;

7) Получением необходимой для производства по делу об административном правонарушении или его рассмотрения информации от государственных органов и лиц;

8) Проведением экспертизы;

9) Взятием проб и образцов;

10) Вручением документов или их копий участникам административного процесса (административного производства).

Так, получение объяснений лица в отношении которого ведется производство по делу об административном правонарушении, а также показаний свидетелей на территории Российской Федерации предусмотрено ст. 26.3 КоАП РФ.

Объяснение лица в отношении которого ведется производство по делу является прямым доказательством по делу об административном правонарушении и имеет большое значение для объективного выяснения всех обстоятельств, а также последующего рассмотрения дела. Вместе с тем, сложность ведения производства по делу об административном правонарушении в отношении участников внешнеэкономической деятельности, являющихся иностранными лицами, заключается в том, что в ряде случаев они покидают территорию Российской Федерации и уклоняют- 
ся от административной ответственности. Ввиду чего, представляется невозможным получить объяснения лица в отношении которого ведется производство по делу об административном правонарушении.

Аналогичная ситуация касается и получения показаний свидетелей, проживающих на территории иностранного государства. Ввиду чего, в таких случаях целесообразно поручить проведение опроса лица, в отношении которого ведется административный процесс, либо свидетеля должностным лицам иностранного таможенного органа на основании направляемого запроса об оказании правовой помощи по делу об административном правонарушении. По результатам опроса составляется протокол, с содержанием которого опрашиваемое лицо знакомится и заверяет его личной подписью, если не имеет с ним разногласий. В дальнейшем данный протокол должен быть направлен с ответом на запрос об оказании правовой помощи в запрашивающий таможенный орган.

Проведение осмотра принадлежащих юридическому лицу или индивидуальному предпринимателю помещений, территорий и находящихся там вещей и документов относится к мерам процессуального обеспечения административного производства, применяемых с целью своевременного и правильного рассмотрения административного дела, и регулируется на территории Российской Федерации ст. 27.8 КоАП РФ.

Данная мера процессуального обеспечения также характеризуется принудительным созданием условий, способствующих установлению факта правонарушения, обнаружению и исследованию доказательств путем визуального осмотра товаров, транспортных средств, документов на них, а также помещений, территорий, где совершено правонарушение. Таким образом, по своей сущности эти меры представляют собой «урегулированные административно-процессуальными нормами принудительные процессуальные действия должностных лиц таможенных органов, направленные на обнаружение, фиксацию, надлежащее изъятие и сохранение доказательств по делу об административном правонарушении» 4

О проведенном осмотре помещений, территорий, находящихся там вещей и документов, должностным лицом иностранного таможенного органа

4 Погодина, Н.А. Административно-правовое регулирование таможенного досмотра / Н.А. Погодина // Административное и муниципальное право. 2010. № 12. - С. 69. составляется протокол, к которому также прилагаются фото- и киносъемки, видеозаписи, иные способы фиксации вещественных доказательств, в случае их применения, который в дальнейшем направляется в запрашивающий таможенный орган и служит доказательством по делу об административном правонарушении.

Изъятие товаров и документов, являющихся вещественными доказательствами или предметами административного правонарушения, представляет собой согласно ст. 27.10 КоАП РФ принудительную меру обеспечения производства по делам об административных правонарушениях, направленную на сбор вещественных доказательств по данным делам, а также на недопущение продолжения использования орудий совершения или предметов административного правонарушения в противоправных целях.

Представляется, что данная административно-процессуальная мера в соответствии с направляемым запросом об оказании правовой помощи может быть применена как к лицу в отношении которого ведется производство по делу об административном правонарушении, так и к лицу, вина которого в совершении административного правонарушения уже установлена вступившим в законную силу постановлением о назначении административного наказания.

При этом важно отметить, что порядок направления изъятых по запросу вещей и документов в настоящее время никак не урегулирован. В этой связи, если направление изъятых документов не вызывает каких либо трудностей, то вопрос о том, каким образом должны направляться изъятые вещи в запрашивающее государство, остается открытым и требует надлежащего разрешения.

Арест товаров и иных вещей, являющихся вещественными доказательствами или предметами административного правонарушения, как и изъятие товаров и документов, также является мерой обеспечения производства по делам об административных правонарушениях, направленной на сбор вещественных доказательств по административным делам, и носит принудительный характер. Применение указанной меры в ходе производства по делу об административном правонарушении на территории Российской Федерации регламентировано ст. 27.14 КоАП РФ.

Следует подчеркнуть, что основным отличием ареста товаров и иных вещей от изъятия товаров и документов является то, что арест применяется в случае, если товары и иные вещи изъять невоз- 
можно и (или) их сохранность может быть обеспечена без изъятия.

Как заметил А.Ю. Анненков, «правовая природа данного действия состоит в составлении описи товаров и иных вещей с объявлением лицу, в отношении которого применена данная мера обеспечения производства по делу об административном правонарушении, либо его законному представителю о запрете распоряжаться (а в случае необходимости и пользоваться) ими»5. Главное же назначение ареста товаров и иных вещей, являющихся вещественными доказательствами или предметами административного правонарушения, состоит в фиксации, сборе доказательств с целью всестороннего, объективного и полного установления обстоятельств рассматриваемого дела об административном правонарушении.

Истребование сведений и документов, необходимых для производства по делу об административном правонарушении, на территории Российской Федерации предусмотрено ст. 26.10 КоАП РФ. Суть данной административно-процессуальной меры заключается в том, что должностное лицо таможенного органа Российской Федерации, в случае необходимости получения сведений и документов из-за рубежа направляет официальный запрос об оказании правовой помощи в иностранный таможенный орган, в котором излагает соответствующую просьбу.

Так, должностное лицо таможенного органа Российской Федерации, в производстве которого находится дело об административном правонарушении, вправе требовать предоставления в соответствии с КоАП РФ от организаций необходимых документов и сведений. Ввиду чего, в случае если истребовать документы и сведения необходимо у иностранного лица, то должностное лицо таможенного органа Российской Федерации подготавливает и направляет в установленном порядке соответствующий запрос об оказании правовой помощи в зарубежный таможенный орган. При получении такого запроса должностное лицо иностранного таможенного органа проводит предусмотренные национальным законодательством запрашиваемого государства процессуальные действия по получению запрашиваемых документов и сведений, и, в дальнейшем, направляет их в российский таможенный орган.

\footnotetext{
5 Анненков, А.Ю. Арест товаров, транспортных средств и иных вещей как мера обеспечения производства по делам об административных правонарушениях / А.Ю. Анненков // Административное право и процесс. - 2011. - № 12. - С. 26.
}

В случае неисполнения требования о предоставлении документов и сведений, должностное лицо зарубежного таможенного органа должно сообщить об этом в запрашивающий таможенный орган с целью рассмотрения последним возможности производства изъятия ранее истребованных документов и сведений. В случае принятия данного решения, должностное лицо таможенного органа Российской Федерации вправе повторно направить запрос об оказании правовой помощи с просьбой о применении изъятия необходимых документов.

Следует обратить внимание, что законодатель в ст. 26.10 КоАП РФ достаточно широко определил источник получения информации, обозначив его термином «организация». Вместе с тем, под организацией в широком смысле слова можно понимать не только все предприятия и организации независимо от их организационно-правовых форм и форм собственности, но и государственные органы, а также общественные и религиозные объединения. Однако, учитывая широкий диапазон составов административных правонарушений, предусмотренных КоАП РФ, а также с точки зрения задач производства по делам об административных правонарушениях и обеспечения прав лица, привлекаемого к административной ответственности, представляется, что термин «организация» в данном случае требует своего толкования в широком смысле слова 6 .

Также отметим, что получение необходимой для производства по делу об административном правонарушении или его рассмотрения информации от государственных органов и лиц не определяется КоАП РФ в качестве самостоятельного процессуального действия, направленного на сбор доказательств по делу. Вместе с тем, данное процессуальное действие предусматривается ст. 10 Coглашения.

Проведение экспертизы также является административно-процессуальной мерой, обеспечивающей получение доказательств по делам об административных правонарушениях. Назначение экспертизы производится в случае, если при производстве по делу возникает необходимость в использовании специальных познаний в науке, технике, искусстве или ремесле и регламентиру-

\footnotetext{
6 Агапов А.Б. Постатейный комментарий к Кодексу Российской Федерации об административных правонарушениях (расширенный, с использованием материалов судебной практики). - Режим доступа: СПС «КонсультантПлюс».
} 
ется на территории Российской Федерации ст. 26.4 КоАП РФ.

В случае принятия решения о необходимости проведения экспертизы на территории иностранного государства, должностное лицо таможенного органа Российской Федерации, в производстве которого находится дело об административном правонарушении, подготавливает и направляет в установленном порядке запрос об оказании правовой помощи с соответствующей просьбой. Таким образом, назначение экспертизы состоит в поручении эксперту в установленном законом запрашиваемого государства порядке исследовать существенные для правильного разрешения дела обстоятельства и дать по ним письменное мотивированное заключение, которое, в последующем, будет направлено в запрашивающий таможенный орган. При этом как справедливо отмечает В.В. Илясов, «главное отличие экспертизы, проводимой за пределами Российской Федерации, и экспертизы, проводимой на территории Российской Федерации, заключается в том, что объекты исследования находятся за границей, а проведение данного процессуального действия является обязательным».7

В соответствии со ст. 26.5 КоАП РФ должностное лицо, осуществляющее производство по делу об административном правонарушении, вправе брать образцы почерка, пробы и образцы товаров и иных предметов, необходимые для проведения экспертизы. В этой связи, должностные лица таможенных органов Российской Федерации впра- ве также направлять в зарубежные таможенные органы запросы об оказании правовой помощи, содержащие просьбы о взятии проб и образцов, необходимых для проведения почерковедческих и товароведческих экспертиз. В этом случае само проведение экспертизы при направлении подобного запроса возможно как запрашиваемым таможенным органом, в случае наличия в запросе одновременно просьбы о проведении экспертизы, так и на территории Российской Федерации, в случае направления взятых проб и образцов и отсутствия таковой просьбы.

КоАП РФ не называет вручение документов или их копий участникам административного процесса в качестве самостоятельного процессуального действия, направленного на сбор доказательств по делу об административном правонарушении. Вместе с тем, ссылка на данное процессуальное действие содержится в ст. 10 Соглашения.

Таким образом, вышеперечисленные процессуальные действия составляют объем правовой помощи по делам об административных правонарушениях запрашиваемой таможенными органами Российской Федерации, а также подлежащей исполнению при получении аналогичного запроса. При этом необходимо учитывать, что, направляя соответствующий запрос в иностранное государство, таможенная служба запрашиваемого государства исполняет поступивший запрос об оказании правовой помощи в соответствии со своим национальным законодательством.

\section{Библиография:}

1. Зубач А.В., Пятикова Е.А., Хомяков Л.Л. Аминистративно-юрисдикционная деятельность таможенных органов: монография. М.: РТА, 2009. - 124 с.

2. О ратификации Конвенции о правовой помощи и правовых от-ношениях по гражданским, семейным и уголовным делам: федер. закон от 04 авг. 1994 г. № 16-ФЗ // Собр. законодательства РФ. - 1994. - № 15. - ст. 1684.

3. Новиков, А.Б. Совершенствование правового обеспечения правоохранительной деятельности таможенных органов / А.Б. Новиков // Внешнеторговое право. 2008. № 2. - Режим доступа: СПС «КонсультантПлюс».

4. Погодина, Н.А. Административно-правовое регулирование таможенного досмотра / Н.А. Погодина // Административное и муниципальное право. 2010. № 12. - С. 66-71.

5. Анненков, А.Ю. Арест товаров, транспортных средств и иных вещей как мера обеспечения производства по делам об административных правонарушениях / А.Ю. Анненков // Административное право и процесс. - 2011. - № 12. - С. 25-28.

6. Агапов А.Б. Постатейный комментарий к Кодексу Российской Федерации об административных правонарушениях (расширенный, с использованием материалов судебной практики). - Режим доступа: СПС «КонсультантПлюс».

7. Илясов В.В. Правовые основы взаимодействия таможенных ор-ганов Российской Федерации и зарубежных стран при ведении производства по делам о нарушении таможенных правил: дис. канд. юрид. наук. Москва, 2002. - 224 с.

\footnotetext{
7 Илясов В.В. Правовые основы взаимодействия таможенных органов Российской Федерации и зарубежных стран при ведении производства по делам о нарушении таможенных правил: дис. канд. юрид. наук. Москва, 2002. - С. 172.
} 


\section{Административное и муниципальное право $9(81) \cdot 2014$}

8. В.Д. Плесовских Тенденции развития федерального административно-деликтного права и законодательства // Право и политика. - 2012. - 12. - С. 1990 - 1994.

9. Стригунова Н.Ю. Доказывание по делам об административных правонарушениях в области таможенного дела в государствах-членах Таможенного союза ЕврАзЭС (сравнительно-правовой анализ) // Административное и муниципальное право. - 2013. - 10. - C. 980 - 985. DOI: 10.7256/1999-2807.2013.10.9765.

\section{References (transliterated):}

1. Zubach A.V., Pyatikova E.A., Khomyakov L.L. Aministrativno-yurisdiktsionnaya deyatel'nost' tamozhennykh organov: monografiya. M.: RTA, 2009. - 124 s.

2. O ratifikatsii Konventsii o pravovoi pomoshchi i pravovykh ot-nosheniyakh po grazhdanskim, semeinym i ugolovnym delam: feder. zakon ot 04 avg. 1994 g. № 16-FZ // Sobr. zakonodatel'stva RF. - 1994. - № 15. - st. 1684.

3. Novikov, A.B. Sovershenstvovanie pravovogo obespecheniya pravookhranitel'noi deyatel'nosti tamozhennykh organov / A.B. Novikov // Vneshnetorgovoe pravo. 2008. № 2. - Rezhim dostupa: SPS «Konsul'tantPlyus».

4. Pogodina, N.A. Administrativno-pravovoe regulirovanie tamozhennogo dosmotra / N.A. Pogodina // Administrativnoe i munitsipal'noe pravo. 2010. № 12. - S. 66-71.

5. Annenkov, A.Yu. Arest tovarov, transportnykh sredstv i inykh veshchei kak mera obespecheniya proizvodstva po delam ob administrativnykh pravonarusheniyakh / A.Yu. Annenkov // Administrativnoe pravo i protsess. - 2011. - № 12. S. 25-28.

6. Agapov A.B. Postateinyi kommentarii k Kodeksu Rossiiskoi Federatsii ob administrativnykh pravonarusheniyakh (rasshirennyi, s ispol'zovaniem materialov sudebnoi praktiki). - Rezhim dostupa: SPS «Konsul'tantPlyus».

7. Ilyasov V.V. Pravovye osnovy vzaimodeistviya tamozhennykh or-ganov Rossiiskoi Federatsii i zarubezhnykh stran pri vedenii proizvodstva po delam o narushenii tamozhennykh pravil: dis. kand. yurid. nauk. Moskva, 2002. - $224 \mathrm{~s}$.

8. V.D. Plesovskikh Tendentsii razvitiya federal'nogo administrativno-deliktnogo prava i zakonodatel'stva // Pravo i politika. 2012. - 12. - S. 1990 - 1994.

9. Strigunova N.Yu. Dokazyvanie po delam ob administrativnykh pravonarusheniyakh v oblasti tamozhennogo dela $\mathrm{v}$ gosudarstvakh-chlenakh Tamozhennogo soyuza EvrAzES (sravnitel'no-pravovoi analiz) // Administrativnoe i munitsipal'noe pravo. - 2013. - 10. - S. 980 - 985. DOI: 10.7256/1999-2807.2013.10.9765. 